\title{
Að leika guð - framfarir í erfðafræði
}

Nýlega hefur orðið gríðarmikil aukning í getu okkar til að breyta erfðamengi manna og dýra. Petta byggir á tveimur uppgötvunum sem komið hafa úr rannsóknum á einskonar ónæmiskerfi baktería, en pað eru kerfi sem hjálpa bakteríum að verja sig fyrir veirusýkingum. Fyrst var uppgötvað kerfi skerðiensíma ${ }^{1}$ sem leyfir bakteríum að skera erfðamengi veira á frekar almennan hátt en pessi uppgötvun markaði upphafið á líftæknibyltingunni. Nýjasta afurð pessarar byltingar er líftæknilyfið nusinersen (spinraza) sem tekið var í notkun á Íslandi 2018 til að meðhöndla alvarlegan taugasjúkdóm í börnum. Seinni uppgötvunin snýr að enn sértækara kerfi úr bakteríum sem heitir CRISPRCas9 kerfi $^{2}$ en petta kerfi hjálpar bakteríum að eyða kerfisbundið veirum úr erfðamengi sínu með pví að læra að pekkja og skera sértæk svæði í veirunum með afar fullkomnum hætti. CRISPR-Cas9 kerfið gerir nú vísindamönnum meðal annars kleift að setja stökkbreytingar sem finnast í sjúklingum í bæði frumur og tilraunadýr með meiri virkni og á mun fljótlegri máta en áđur var hægt. Pessi uppgötvun breytir pví hvernig vísindamenn próa og prófa nýjar meðferðir í gegnum færsluvísindi (translational medicine), sem er рað svið sem snýr að færslu grunnuppgötvana til sjúklinga, en afurð grunn- og færsluvísinda getur verið einstaklega verðmæt og hefur til dæmis Bandaríska matsstofnunin (National Institute of Standards and Technology) metið að hver Bandaríkjadalur sem fer í slíkar rannsóknir skilar sér 44-falt til baka til bandarísks pjóðfélags. ${ }^{3}$

Pessi bylting mun auka pörfina fyrir pjálfun heilbrigðisstarfsmanna með pekkingu á erfðafræði og færsluvísindum og er augljóst að á allra næstu árum verður einnig gríðarlega mikilvægt að tilraunadýrahús rísi í „Vísindaporpinu í Vatnsmýrinni” til að tryggja eðlilega frampróun lífvísinda á Íslandi. Pessar tvær uppgötvanir sýna mikilvægi grunnrannsókna fyrir framfarir í læknisfræði og sýna hve erfitt er að spá fyrir um hvaða rannsóknir eiga eftir að hafa mestu áhrifin. Pað er pví afar mikilvægt að hafa öflugt styrkjakerfi fyrir grunn- og færsluvísindi á heilbrigðissviði til pess að við getum tekið pátt í pessari byltingu.

CRISPR-Cas9 kerfið gefur einnig kost á meðferðarmöguleika par sem beinlínis verður hægt að leiðrétta sjúkdómsvaldandi stökkbreytingar í frumum. Hægt er að gera petta með pví að koma CRISPR-Cas9 og leiðsögusameind inn í frumur í vef sem liggur vel við höggi. Hinn möguleikinn er að fjarlægja frumur úr sjúklingi, erfðabreyta peim og skila peim aftur til sjúklingsins. Búast má við miklum vexti í pessum geira og sést pað nú pegar í birtum greinum á sviðinu. Hins vegar má búast við pví að pessar breytingar verði helst gerðar í líkamsfrumum pví pað eru fáar ástæður til að breyta kímlínunni til að meðhöndla sjúkdóma. Eitt slíkt dæmi væri ef báðir foreldrar væru arfhreinir fyrir sjúkdómsbreytingu í sama geni, en slíkir foreldrar gætu ekki átt barn án erfðasjúkdóms. Pví kom pað ekki á óvart að í skýrslu sinni um petta málefni ${ }^{4}$ skyldi Ameríska vísindaakademían (NAS) mælast til pess að petta kerfi yrði einungis notað í kímfrumum að yfirveguðu máli til að meðhöndla eða fyrirbyggja alvarlegt sjúkdómsástand. Hins vegar tók pað vísindamanninn He Jiankui við SUSTech háskólann í Kína einungis eitt ár að brjóta petta ákvæði vísindaakademíunnar pegar hann erfðabreytti tveimur fósturvísum, sem leiddi til pess að fyrstu erfðabreyttu einstaklingarnir fæddust í lok árs 2018. Petta gerði He að eigin sögn til að draga úr líkum á HIV-smiti frá HIV- jákvæðu foreldri. Hins vegar eru nú pegar til staðar góðar aðferðir til að draga úr slíku smiti og líklegra er að hann hafi með pessu móti vonast til pess að gera nafn sitt ódauðlegt. Einnig kom í ljós að hvorugt barnanna hafði tilætlaða breytingu og breytingin fannst einungis í sumum frumnanna. He var rekinn frá SUSTech og hefur pessi notkun á CRISPR-Cas9 tækni síðan verið fordæmd af vísindasamfélaginu. En pað breytir ekki peirri staðreynd að nú hafa fæðst fyrstu erfðabreyttu manneskjurnar með illa ígrundaðar erfðabreytingar.

Рað er pví afar mikilvægt að við tryggjum skynsamlega notkun á CRISPR-Cas9 í gegnum alpjóðleg samskipti með takmörkunum á getu manna til að breyta kímlínunni. Um leið er mikilvægt að fjárfesta í pessari byltingu með pví að pjálfa næstu kynslóð lækna, lífvísindamanna, erfðafræðinga og siðfræðinga. Á pessum tímapunkti eru margar nýjar leiðir par sem pessi tækni gæti gjörbreytt meðferðarmöguleikum sjúklinga okkar án pess að nokkur möguleiki sé á breytingu á kímlínunni. ${ }^{5}$ Við erum öll hluti af byltingu sem á eftir að gjörbreyta klínísku starfi á næstu áratugum og við ættum öll að vera vel upplýst um hvað er að gerast á pessum nýja vettvangi.

\section{Heimildir}

1. Kelly TJ Jr, Smith HO. A restriction enzyme from Hemophilus influenzae. II. J Mol Biol 1970; 51: 393-409.

2. Jinek M, Chylinski K, Fonfara I, Hauer M, Doudna JA, Charpentier E. A programmable dual-RNA-guided DNA endonuclease in adaptive bacterial immunity. Science 2012, 337: 816-21.

3. nist.gov/speech-testimony/importance-basic-research-united-statescompetitiveness - febrúar 2019.

4. National Academies of Sciences Engineering and Medicine. Human genome editing: science, ethics, and governance. The National Academies Press (U.S.) Google Scholar. Washington DC 2017.

5. Hilton IB, D'Ippolito AM, Vockley CM, Thakore PI, Crawford GE, Reddy TE, et al. Epigenome editing by a CRISPR-Cas9-based acetyltransferase activates genes from promoters and enhancers. Nat Biotechnol 2015; 33: 510-7.

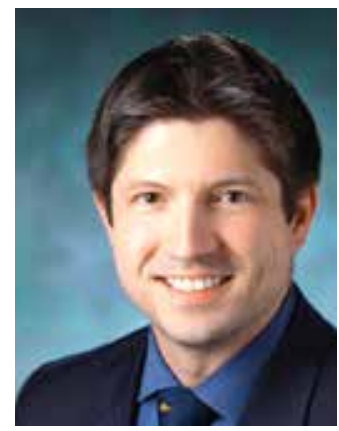

\section{Hans Tómas}

\section{Björnsson}

læknir

Erfða og

sameindalæknisfræðideild

Landspítala,

færsluvísindum og

barnalækningum

Háskóla Íslands,

erfðafræði og

barnalækningum

Johns Hopkins háskóla.

hanstb@landspitali.is

\section{Playing god - progress in genomic medicine}

Hans Tómas Björnsson MD PhD Clinical Director, Clinical Genetics, Landspitali University Hospital, Associate Professor, Translational Medicine and Pediatrics, University of Iceland, Associate Professor, Genetics and Pediatrics, Johns Hopkins University.

doi.org/10.17992//bl.2019.03.219 